\title{
Canine Hemorrhagic Enteritis: Detection of Viral Particles by Electron Microseopy
}

\author{
By \\ G. Burtonboy ${ }^{1}$, F. Colgnoul 2 , N. Delferriere ${ }^{1}$, and P. P. PastoreT ${ }^{3}$ \\ 1 Laboratoire de Virologie, Faculté de Médecine, Université Catholique de Louvain, \\ Brussels, Belgium \\ 2 Laboratoíre de Pathologie, Faculté de Médecine Vétérinaire, Université de Liège, \\ Brussels, Belgium \\ 3 Laboratoire de Virologie, Faculté de Médecine Vétérinaire, Université de Liège, \\ Brussels, Belgium \\ With 6 Figures
}

Accepted March 20, 1979

\section{Summary}

At necropsy, several dogs which died showing symptoms of hemorrhagic diarrhea, had significant lesions of the mucosa that were found especially in the duodenum and upper part of the small bowel.

Study of ultrathin sections from the diseased mucosa revealed particles resembling parvoviruses in altered nuclei of cells of the intestinal crypts.

Electron microscopic examination of intestinal contents by negative staining has shown the presence of many viral particles which have a diameter of $24 \mathrm{~nm}$ and whose profile is consistent with an icosahedral shape. These virions float at a density of $1.43 \mathrm{~g} / \mathrm{cm}^{3}$ in cesium chloride and agglutinate rhesus monkey and swine red blood cells at $4^{\circ} \mathrm{C}$.

A possible etiological role in discussed.

This virus is compared with the minute virus of canines and the Feline Panleukopenia virus.

\section{Introduction}

During this last year, among the dogs sent for autopsy to the school of veterinary medicine, seven cases, diagnosed as having fatal hemorrhagic enteritis, showed some interesting similarities.

They all died after an episode of two or three days with vomiting and a bloody diarrhea. These animals were mature dogs coming from different breeding and sheltering centers. In each case the disease had occurred during the week of their arrival at the kennel.

At necropsy the duodenum and proximal part of the small bowel appeared very congested. Histological examination of these organs showed necrosis of the 
villi and profound abnormalities of the crypts. The lumens of the crypts were enlarged, sometimes filled with debris, and their epithelium, often discontinuous, was composed of flat cells with a clear swollen nucleus (6).

No bacterial pathogen was consistently found in these cases nor could any poisonous substance be identified as the cause of death.

In view of the characteristic mucosal lesions (22) a viral etiology was suspected.

To investigate this unusual syndrome we used various technics of electron microscopy which already have been successfully applied to the study of viral diarrheas in man $(2,5,17)$ and animals (28).

We describe here the results of direct examination of the feces by negative staining and the analysis of ultrathin sections of the diseased part of the intestinal tract of these dogs.

\section{Materials and Methods}

Samples were obtained from 7 dogs which died during an episode of hemorrhagic diarrhea. The cases comprised 1 . a four year-old female basset hound, 2 . a two year-old male basset hound, 3, a one year-old male german shepherd, 4. a two year-old female basset hound, 5 . a five year-old male dalmatian, 6 . a one year-old male mongrel dog and 7. a two year-old male poodle.

When it was realized that all these animals had similar histological lesions of the gut, we further analysed the organs which had been removed at the time of autopsy.

Specimens of feces from seven apparently normal dogs were also examined.

\section{Viral Suspension}

Portions of intestine from 3 animals (no. 1,6,7) had been ligated and maintained at $-20^{\circ} \mathrm{C}$. After thawing, the contents of each were diluted one to ten in distilled water and clarified by centrifugation at $3000 \mathrm{rpm}(1500 \times \mathrm{g})$ for 20 minutes. The supernatant was used for direct examination by E. M., hemagglutination test, equilibrium density gradient centrifugation and virus isolation studies.

\section{Direct Examination by Electron Microscopy (E. M.)}

Specimens were prepared according to the pseudo-replica method described by SMrTH (26).

Briefly, a drop (20 microliters) of viral suspension was placed on a block of special agar Noble (ref. 0/4201 DIFCO Detroit Mi.) at a concentration of 4 per cent in water. The agar block was cut so that there was a $1 \mathrm{~cm}^{2}$ area on which the drop containing the viruses was evenly spead. After the liquid had penetrated into the gel and after the surface appeared dry, it was covered with a drop of collodion (1 per cent nitrocellulose in amyl acetate; Ernest Fullam Inc.). After drying, the thin layer of collodion was floated off onto an aqueous solution of 1 per cent potassium phosphotungstate at pH 7 . The floating membrane entrapped the viral particles which were deposited on the agar. This membrane was then placed on a carbon-coated grid and examined in the E. M. at $80 \mathrm{kV}$.

The size of the virions was estimated from photographs. A tracing of the profiles of the particles was analyzed by an image analyzer (Quantimet). E. M. Magnification was estimated by using a gold erystal replica (Balzers Union).

\section{Serological Studies}

Stagloban (Behring) was used as a commercial source of dog immunoglobulin. We also tested sera from 3 apparently normal dogs living in a kennel where one animal (no. 3) had died with hemorrhagic enteritis several weeks before. 
Immunoelectron Microscopy (I.E.M.)

One drop (20 microliters) of a dilution of immunoglobulin solution was added to the same volume of viral suspension. After 1 hour at $37^{\circ} \mathrm{C}$, the mixture was left overnight at $4^{\circ} \mathrm{C}$ and then examined by the pseudoreplica procedure.

Hemagglutination and Hemagglutination Inhibition (H.A. and H.I.)

Tests were performed in microplates (Cooke). Samples were diluted in a saline solution $\left(9 \mathrm{~g} \mathrm{NaCl}, 100 \mathrm{mg} \mathrm{MgCl} 2\right.$ and $30 \mathrm{mg} \mathrm{CaCl} 2$ in $11 \mathrm{H}_{2} \mathrm{O}$ ) by means of an automatic diluter (Cooke eng. Co. Va. U.S.A.).

Rhesus monkey erythrocytes were obtained from the Pasteur Institut (Paris). Red blood cells were washed three time and adjusted to a final concentration of $5 \times 10^{4}$ cells per $\mathrm{mm}^{3}$ in the same saline. One drop (20 microliters) of this erythrocyte suspension then was added to each well of the microplate containing the sample dilutions. Hemagglutination titers were read by the pattern method after being left overnight at $4^{\circ} \mathrm{C}$.

For hemagglutination inhibition tests, sera were treated with neuraminidase (Microbiological Associates, Inc. Bethesda Md.) and adsorbed by the red cells (24). Four units of antigen were mixed with the serum dilutions and incubated at $37^{\circ} \mathrm{C}$ for 1 hour. After addition of the red cells, the test was placed at $4^{\circ} \mathrm{C}$ overnight.

\section{Equilibrium Density Gradient}

Three $\mathrm{ml}$ of viral suspension were filtered through a filter of 22 micron pore diameter (Millipore filter GSWP 1300). To the filtrate was added $3.174 \mathrm{~g}$ of Cesium chloride and distilled water to give a final volume of $6 \mathrm{ml}$ of average density $1.396 \mathrm{~g} / \mathrm{cm}^{3}$. This was centrifuged in a swinging bucket rotor (Christ Ultracentrifuge Omega II) at $4^{\circ} \mathrm{C}$ and $40,000 \mathrm{rpm}(280,000 \times g)$ for 40 hours. Twenty one fractions were collected from each sample with a Beckman fraction collector and the density of each estimated from its refractive index.

From each fraction one drop was examined by electron microseopy by negative staining and another for hemagglutinating activity.

\section{Attempted Virus Isolation}

The viral suspension was inoculated onto the following cultures: Madin Darby canine kidney, Madin Darby bovine kidney, Primary human embryo kidney cells, Primary Rhesus Monkey kidney cells and Hela cells. The cells were exposed to the virus when the monolayer was about 25 per cent confluent. Inoculated cultures were incubated at $37^{\circ} \mathrm{C}$ and observed for the development of cytopathic effect.

Samples of the supernatant of these cultures were harvested every day, tested for hemagglutinating activity and examined by E. M. to detect the presence of viral particles.

The virus was also inoculated onto the same type of cells in Leighton tubes - coverslips were fixed in Bouin's solution, stained with hematoxylin eosin and sereened for intranuclear inclusions. route.

Specific pathogen free embryonating eggs were injected by the amniotic or allantoic

\section{E.M. Examination of Ultrathin Sections}

For each animal, pieces of intestine were kept immersed in 10 per cent formalin saturated with calcium carbonate, at room temperature, for from two weeks to four months. They were then washed three times in phosphate buffer $(0.1 \mathrm{~m} \mathrm{pH} \mathrm{7.2)}$ cut in blocks of roughly $1 \mathrm{~mm}^{3}$ and fixed with 2.5 per cent glutaraldehyde (LADD) in the same buffer. They were then washed three times, postfixed for one hour in 1 per cent osmium tetroxide, dehydrated and embedded in Epon by a method recommended by DE Harven (9).

The zones to be studied were chosen on thick sections ( 2 microns) stained by toluidine blue (27). Ultrathin sections were made with a L.K.B. ultramicrotome contrasted by means of uranyl acetate and lead citrate (14) and examined in a Philips E M 300 at $60 \mathrm{kV}$. Photographs were taken on sheet film (Kodak electron microscope film). 


\section{Results}

\section{Examination of Specimens by Negative Staining}

The intestinal contents of 3 dogs (no. 1, 6,7) were examined and all three were shown to contain many viral particles. The outlines of the particles were often round or polygonal and many of them, almost 20 per cent, were penetrated by the phosphotungstate so that they appeared as empty virions.

PROFILE SIZE DISTRIBUTION

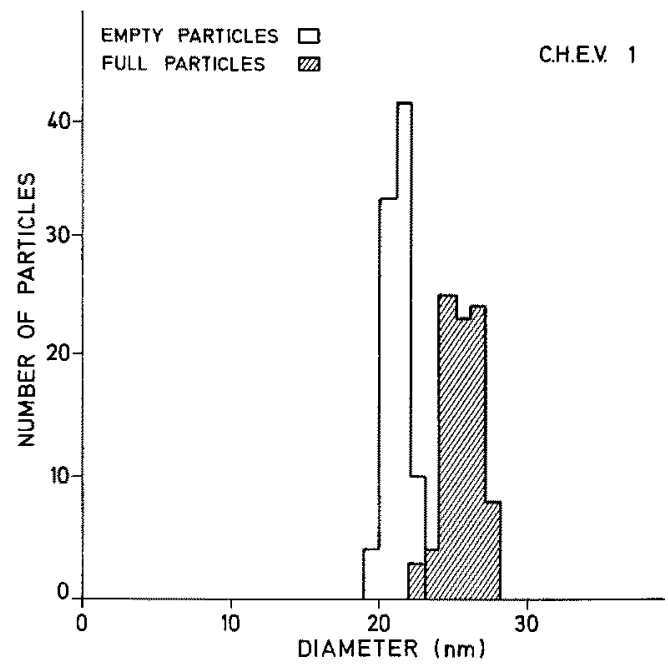

Fig. 1. The profiles of 98 particles found in intestinal content of dog no. 1 (C.H.E.V.) were measured in an image analyzer. Empty particles appear to be smaller

By measuring a large number of profiles it was possible to show that particles which were not penetrated by the stain had a mean diameter of $24.5 \mathrm{~nm}$; with values ranging between 23 and $28 \mathrm{~nm}$. Empty particles were small, their diameters ranging from 19 to $23 \mathrm{~nm}$ with a mean of $21 \mathrm{~nm}$ (Fig. 1). By immunoelectron microscopy the particles were seen agglutinated in large clumps. This phenomenon was observed using a $1 / 10$ dilution of any of the three sera as well as of the commercial dog immunoglobulin (Fig. 2). No such particles were detected in the samples from the healthy animals.

\section{Hemagglutination}

The viral suspensions obtained by clarification of the intestinal contents agglutinated rhesus erythrocytes at $4^{\circ} \mathrm{C}$ and not at $37^{\circ} \mathrm{C}$. For dog no. 1 the titer was 12,800, dog no. 6: 8000, and $\operatorname{dog}$ no, $7: 128$.

The hemagglutination patterns obtained in the cold disappeared at $37^{\circ} \mathrm{C}$ but agglutinated if the cells were redispersed and returned to $4^{\circ} \mathrm{C}$. Swine red blood cells were also agglutinated at $4^{\circ} \mathrm{C}$ and the titers were similar. Human 0 , chicken, pigeon and guinea pig red cells were not agglutinated. 


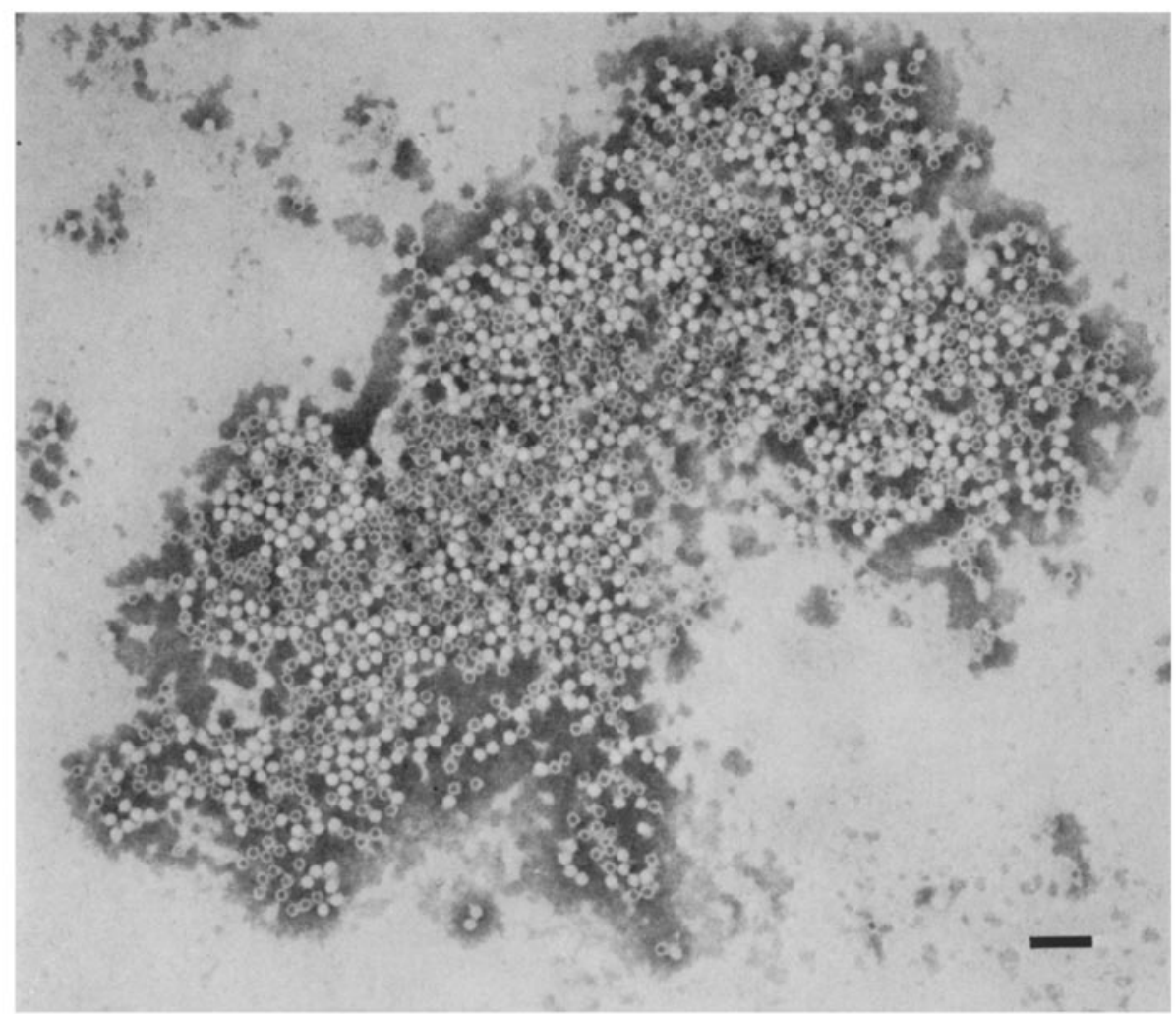

Fig. 2. Particles observed in intestinal content of dog no. 1 after incubation with a $1 / 10$ dilution of dog commercial immunoglobulin (Bar represents $100 \mathrm{~nm}$ )

DISTRIBUTION OF HEMAGGLUTINATING ACTIVITY

IN A CESIUM CHLORIDE DENSITY GRADIENT

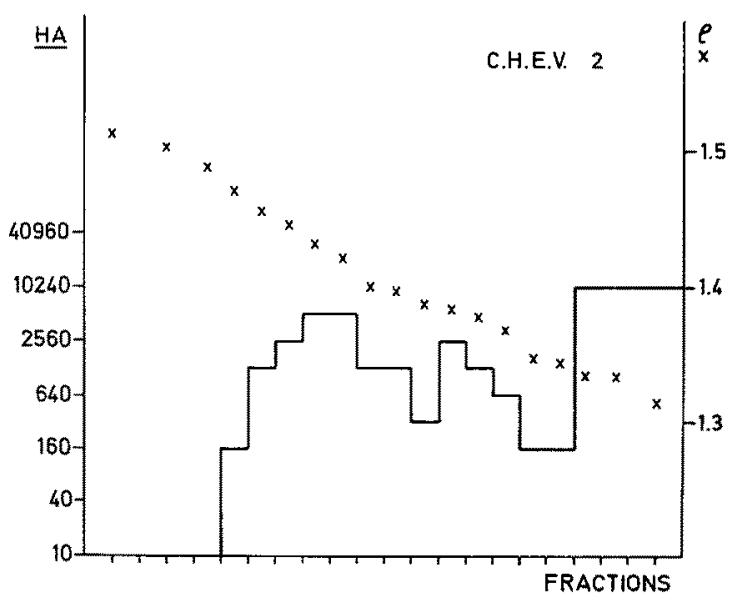

Fig. 3. Viral suspension obtained from dog no. 2 (C.H.E.V.2) was shown by density gradient to contain three peaks of hemagglutinating activity 
When a viral suspension had been filtered through a 22 micron millipore filter, viral particles could still be detected by E.M. but the HA titer was reduced tenfold. The sera of apparently healthy dogs had HI titers greater than 160 .

\section{Density Gradient}

After centrifugation in cesium chloride the hemagglutinating activity was distributed as shown in Figure 3 . The activity was not detected in samples having a density greater than 1.46 but was found in all the remaining fractions with three major peaks at densities of $1.43,1.38$ and 1.34. This was consistently observed in repeated experiments.

The same fractions were examined by immunoelectron microscopy and by this method viruses were also detected in all the fractions with a density less than 1.46.

In the samples corresponding to peak hemagglutinating activity larger numbers of viral particles were also observed by E.M.

At a density of 1.43 only "full" virus particles were seen, at 1.38 equal numbers of "empty" and "full" particles were present, while at a density of 1.34 eighty percent of the virions appeared empty.

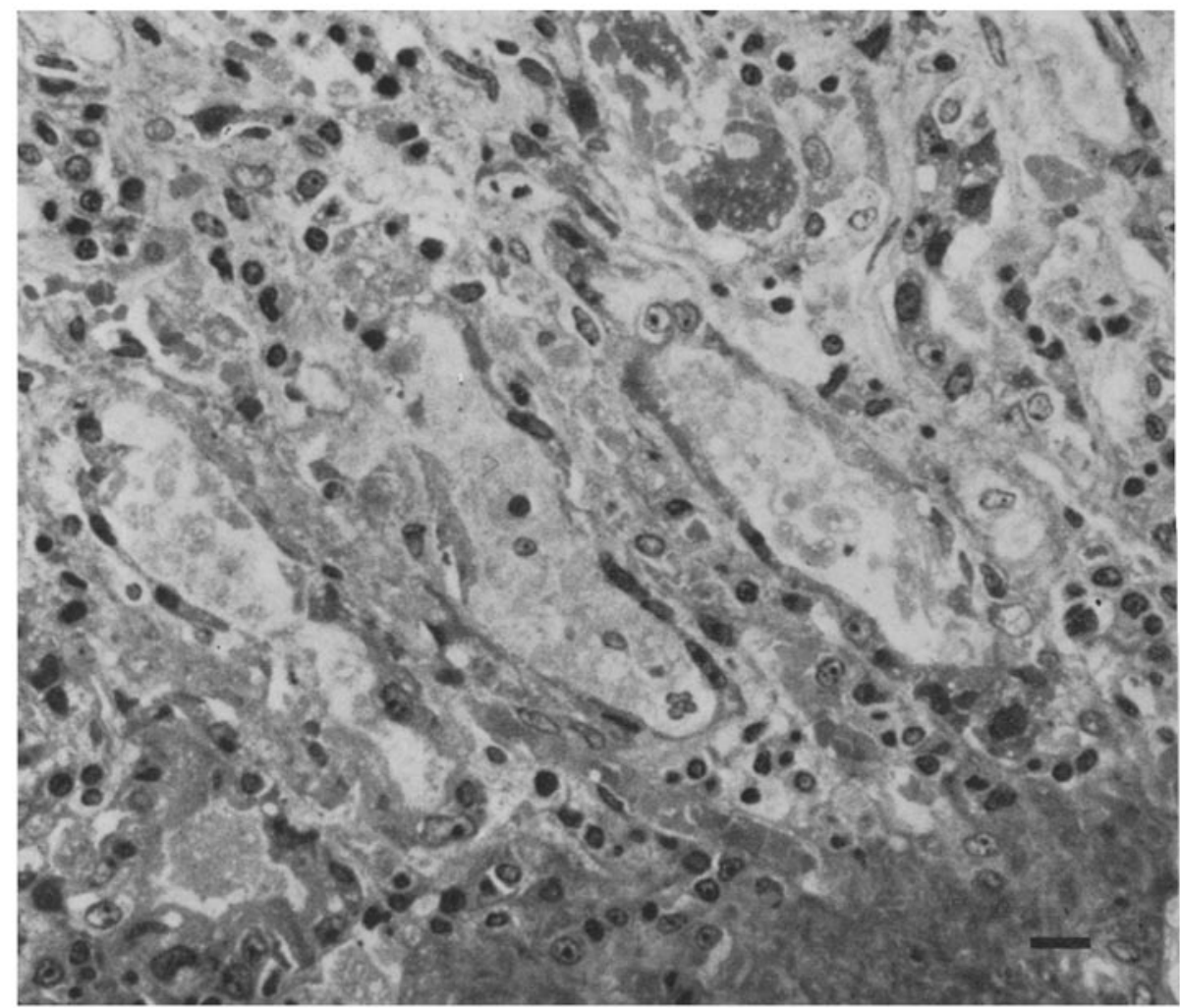

Fig. 4. Section through three ileal crypts which appear to be severely damaged: some swollen nuclei are still visible in the atrophic pattern (Bar represents 20 microns). The semi-thin section of the intestinal mucosa was stainted by Toluidine blue. The area chosen lay between the base of the villi above and the muscularis mucosae below 


\section{Tissue Cullure}

So far attempts to grow this virus in tissue culture have been unsuccessful. No cytopathic effect was observed nor could any intranuclear inclusion be detected. E.M. and hemagglutination test failed to show production of viral particles. No virus was isolated in embryonated hen's eggs.

\section{Examination of Specimens in Thin Section}

For every one of the animals, characteristic alterations of the intestinal wall were clearly seen by light microscopy on semi-thin sections stained with toluidine blue (Fig. 4).

Superficial layers of the'mucosa were necrotic: the general pattern of the villi was preserved and some cell limits were slightly visible but it was not possible to recognize more detail. However in the deeper layer near the muscularis mucosae the structures were easily distinguished. In this region there was significant infiltration with small mononuclear cells. The lumina of the crypts were swollen and contain debris and vacuolated cells. Their epithelium seemed to be discontinuous. It was composed of flat cells, the nuclei of which frequently appeared filled with abnormal granular material. These areas were selected for ultrathin sections.

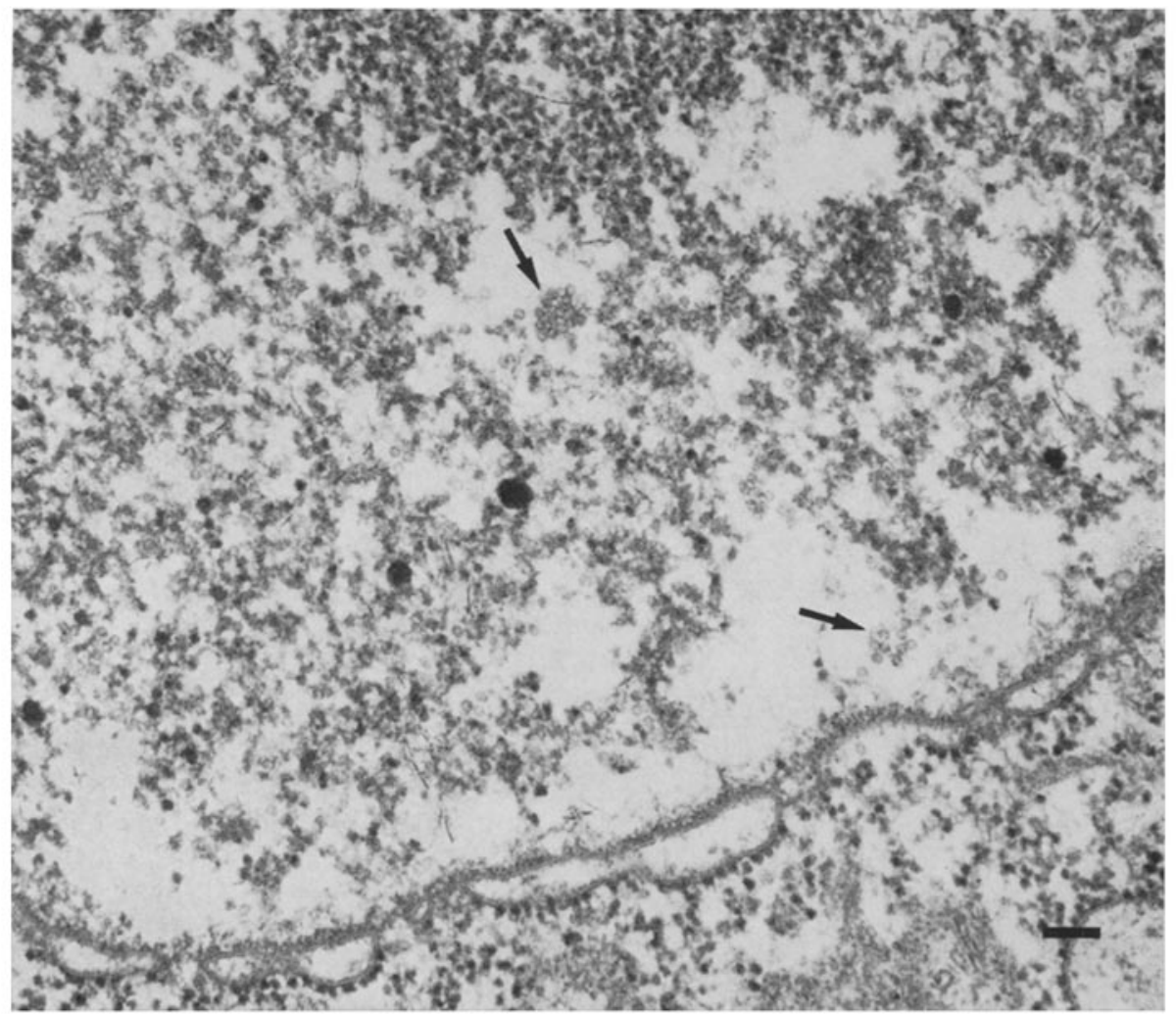

Fig. 5. Presence of round empty particles in the nucleus of an epithelial cell (Bar represents $100 \mathrm{~nm}$ ) 
At the E.M. level most of the cells were severely damaged. Due to the poor quality of preservation of fine structures a precise cytological study was not possible. Nevertheless in cells limiting the crypts viral particles were clearly visible (Fig. 5) and were detected in the nucleus of the epithelial cells. They had a diameter of $20 \mathrm{~nm}$ or less. They were circular in outline with a dense margin and a pale center. In a few of them a central dark spot was apparent. Uniformly dense particles with the same dimension and outline were also present and at least some of them were probably complete virions.

In vacuolar cells floating in the lumen of the mucosal crypts many particles were also found, but in the cytoplasmic area and not in the nucleus. In these cells there were large clumps composed of a mixture of full and empty particles often surrounded by a membrane (Fig. 6). In some of these viras containing vacnoles dense granular material and pseudo myelinic patterns were seen.

Similar observations were made in specimens from each of the seven dogs.

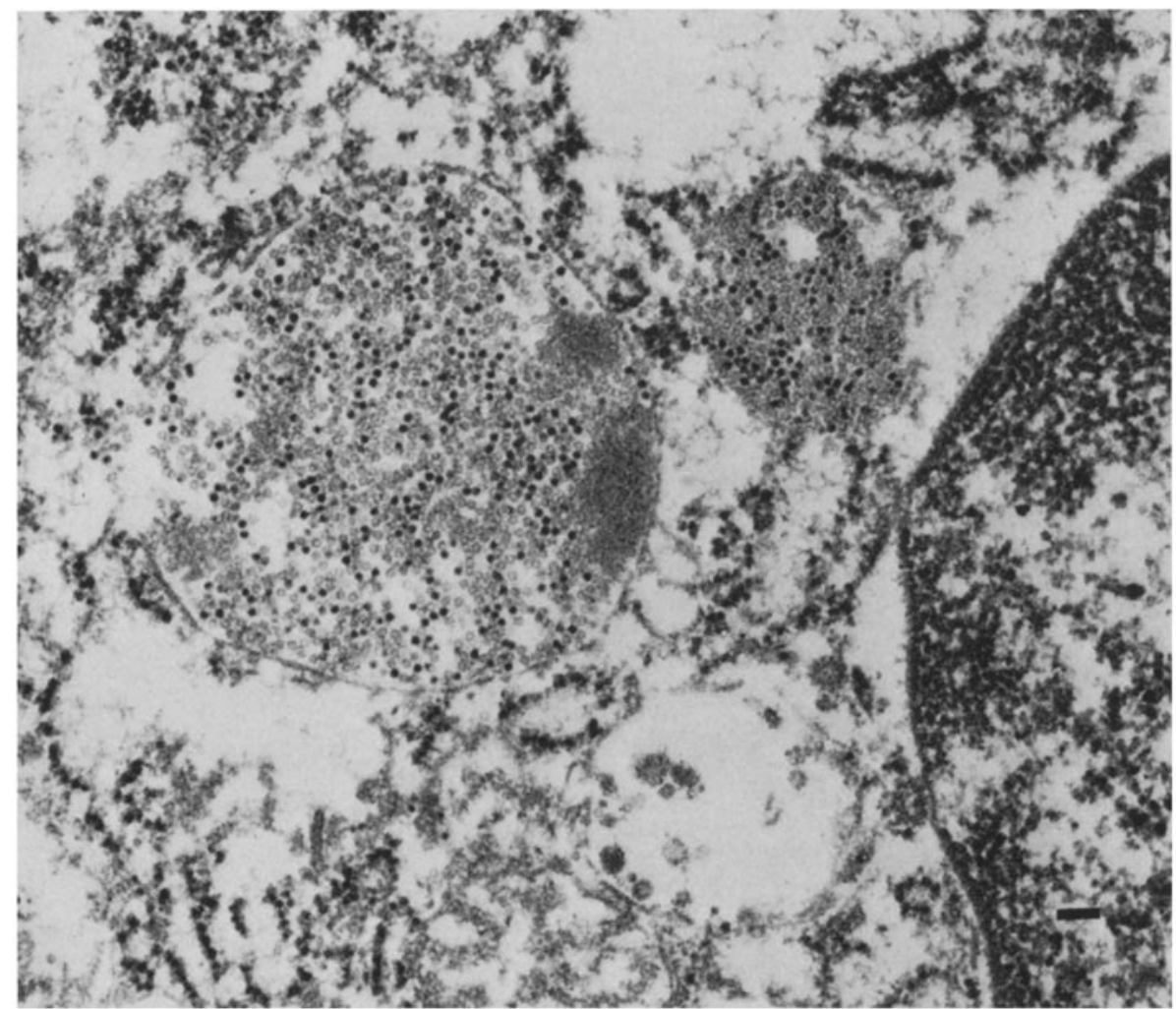

Fig. 6. Clumps of particles in the eytoplasm of a vacuolated cell floating in the lumen of a duodenal crypt. (Bar represents $100 \mathrm{~nm}$ )

\section{Discussion}

The viruses detected in the fecal material of the dogs with hemorrhagic enteritis closely resemble parvoviruses. The morphological characteristics are similar to those described for other viruses of this family $(15,16,25)$. Capsomeres 
were not demonstrated but the hexagonal outline of the virions is consistent with icosahedral symmetry (20).

The dimensions found are in the size range given for the group (13). More precise comparison with the data of the literature may not be meaningful since the diameters of viral particles measured by E.M. can depend on working conditions (25). Furthermore in constant and controlled experimental conditions differences have been reported to exist between strains (18). In addition in our measurements full particles appear larger than empty ones. Therefore reliable estimations of differences can only be made by considering size distributions. Even so homogeneous populations of particles taken from some gradient fractions, can only be compared if the error of the estimate has been determined (21) and large number of particles have been measured.

As for buoyant density, the particles present in the dogs intestinal contents were found to distribute in a cesium chloride equilibrium density gradient as described for some parvoviruses $(16,25)$. For example for minute virus of mice the hemagglutinating activity was shown to peak at exactly the same densities, that is 1.43 and 1.34 with an additional peak at $1.38(8)$.

The presence of numerous parvovirus-like particles in the feces fits very well with the histological lesions observed in the same animals by light microscopy. Such crypt injuries are well known in enteritis due to a parvovirus (19). A virus cytopathic effect causing mucosal damage would readily explain the hemorrhagic diarrhea syndrome. This would be supported by the detection of viral particles in the cells (7). We have examined material removed at the time of autopsy even though it had not been fixed for ultrastructural study (10). The fine structures were in fact spoiled either by postmortem artifacts or by poor fixation procedures but the presence of virions was obvious. The particles found in the nuclei of the abnormal epithelial cells of the mucosal crypts were quite similar to what has been described in cells inoculated with a parvovirus (23).

If we assume that the virions of the intestinal content are produced by the infected duodenal cells, the presence of the particles in the nucleus is strong evidence that they belong to the Parvovirus group.

If this dog agent turns out to be a parrovirus it might in fact be the minute virus of canines (M.V.C.) which was proposed ten years ago as a member of the genus Parvoviridae (4). Some evidence to support this idea came from the observation that the canine hemorrhagic enteritis virus (C.H.E.V.) and the minute virus of canines both agglutinated rhesus monkey erythrocytes at $4^{\circ} \mathrm{C}$ though it was reported that M.V.C. does not agglutinate pig red cells (25).

The M.V.C. was known to grow and produce a cytopathic effect in only one cell line: the Walter Reed canine cell (W.R.C.C.). Since these cells were no longer available (SIEGL, personal communication) it was not possible to determine if the virus found in dog enteritis had this same property. Using cells other than W.R.C.C. we were unable to culture the virus. But such negative results should not be considered as conclusive. Attempts to cultivate the virus are continuing.

The M.V.C., isolated from apparently healthy animals was not thought to be pathogenic (3), though it had been suspected to be related to mild diarrhea in puppies (11). In the cases we have studied we found virions only in animals with a specific intestinal syndrome and not in apparently healthy dogs. But of course 
by E.M. or HA it is not possible to detect viral particles except when they are present in large quantities.

Among the other parroviruses the feline panleukopenia virus has been shown to cause in cats and minks an enteritis with very similar lesions of the intestinal crypts (19). FPLV has been reported to agglutinate swine erythrocytes but rhesus red cells were not tested (25). This hemagglutination occurs at $4^{\circ} \mathrm{C}$ with the same disaggregation at room temperature and aggregation on returning to the cold.

Little information is available on the importance of this parvoviral infection in dogs. Recently, outbreaks of canine parvovirus-like viral enteritis have been reported in various locations throughout the United States $(1,12)$.

Until now we have only had the opportunity to examine autopsy material. Investigations in living animals with symptoms of enteritis such as vomiting and diarrhea could be a source of additional information. If many particles are present in feces they could be detected by E.M. or HA.

On the other hand IHA and I.E.M. recognize the presence of antibodies in the serum. In non fatal cases it should be possible to make the diagnosis and to demonstrate a seroconversion. It is conceivable that severe or even fatal disease may occur in adult dogs which lack immunity when they arrive in a new kennel and come in contact with dogs which are immunized but carry the virus.

This is still an hypothesis and needs to be substantiated by further studies.

\section{Acknowledgments}

We are grateful to Prof. L. E. Carmichael, James A. Baker Institute for animal health, Cornell University, Ithaca, N.Y., to Prof. D. V. Coleman, St. Mary's Medical School, London, and to Dr. A. M. Field, Virus Reference laboratory, Colindale, London, for helpful suggestions and critical review of the manuseript.

Dimensions of the particles were estimated with the help of Bernard Thiry using suitable programs supplied by Prof. P. Baudhuin of the International Institute of Cellular and Molecular Pathology in Brussels. The authors would like to acknowledge them.

\section{References}

1. Appex, M. J. G., Cooper, B. J., Greisen, H., Carmichaet, L. E. : Status report: canine viral enteritis. J. Amer. vet. med. Ass. 173, 1516-1518 (1978).

2. Afpleton, H., Bucklex, M., Thom, B. T., Cotmon, J. L., Henderson, S.: Vírus like particles in winter vomiting disease. Lancet $\mathrm{i}, 409-411$ (1977).

3. Binn, L. N., Eddy, G. A., Lazar, E. C., Helms, J., Murname, T.: Viruses recovered from laboratory dogs with respiratory disease. Proc. Soc. exp. Biol. Med. 126, $140-145$ (1967).

4. Binn, L. N., Lazar, E. C., Eddy, G. A., KajiMa, M. : Recovery and characterization of a minute virus of canines. Infect. Immun. 1, 503-508 (1970).

5. Bishop, R. F., Davidoson, G. P., Holmes, I. H., Ruck, B. J.: Virus particles in epithelial cells of duodenal mucosa from children with acute non bacterial gastroenteritis. Lancet 2, 1281-1283 (1973).

6. Coigroul, F., Dewaele, A.: Canine haemorrhagic enteritis. Pathology of a syndrome. Ann. med. Vet. 123, 47-54 (1979).

7. Coleman, D. V., Russeic, W. J. I., Hodgson, J., Tun Pe, Mowbray, J. F.: Human papovavirus in Papanicolaou smears of urinary sediment detected by transmission electron microscopy. J. clin. Pathol. 30, 1015-1020 (1977).

8. CRAWford, L. V.: A minute virus of mice. Virology 29, 605-612 (1966). 
9. De Harven, E. : Methods in electron microscopic cytology. In : Busch, Harris (ed.), Methods in Cancer Research, Vol. I, 3-42. New York: Academic Press 1967.

10. DoAne, F. W., ANDErson, N.: Electron and Immunoelectron microscopy. In: Kurstak, E., Kurstak, C. (eds.), Comparative diagnosis of viral diseases, Vol. II, part B, 505-539. New York-San Francisco-London: Academic Press 1977.

11. Eugster, A. K., NAJRN, C.: Diarrhea in puppies: parvovirus like particles demonstrated in their feces. South West Vet. 30, 59-60 (1977).

12. Eugster, A. K., Bendele, R. A., Jones, L. P.: Parvovirus infection in dogs. J. Amer. vet. med. Ass. 173, $1340-1341$ (1978).

13. Fenner, F.: In: Classification and nomenclature of viruses (second report of the international committee on taxonomy of viruses), 115. Basel: S. Karger 1976.

14. Hayat, M. A.: Principles and techniques of electron microscopy (Biological applications, Vol. I), 412. New York: Van Nostrand Reinhold \& Co. 1970.

15. Horzinek, M., Mussgay, M., Maess, J., Pexzoldt, K.: Nachweis dreier Virusarten in einem als cytopathogen bezeichneten Schweinpest-Virusstamm. Arch. ges. Virusforsch. 21, 98-112 (1967).

16. Johrson, R. H., Siegt, G., Gautschi, M.: Characteristics of Feline Panleukopenia, virus strains enabling definitive classification as parvoviruses. Arch. ges. Virusforschung 46, 315-324 (1974).

17. Kapikian, A. Z., Hyun Wha Kum, Wyatt, R. G., Lee Cuine, W., Parrot, R. H., Chanock, R. M., Arrobio, J. O., Brandt, C. D., Rodrteutz, W. J., Kalica, A. R., VAX KIRK, D. N.: Recent advances in the aetiology of viral gastroenteritis. In: Acute Diarrhea in childhood. Ciba Foundation Symposium 42 (new series), 273 to 309. Amsterdam-Oxford-New York: Elsevier-Excerpta Medica-North Holland 1977.

18. KARAKASI, S.: Size and ultrastructure of the H-viruses as determined with the use of specific antibodies. J. ultrastruct. Res. 16, 109-122 (1966).

19. KENT, T. H., Moon, H. W. : The comparative pathogenesis of some enteric diseases. Vet. Pathol. 10, 414-469 (1973).

20. Mayr, A., Bachmann, P. A., Stegl, G., Shefry, B. E. : Characterisation of a small porcine DNA virus. Arch. ges. Virusforsch. 25, 38-51 (1968).

21. Mood, A. M., Graybirm, F. A.: p. 248. Introduction to the theory of statistics, 2nd ed., 443. New York: McGraw-Hill 1963.

22. Moon, H. W. : Mechanisms in the pathogenesis of diarrhea. J. Amer. vet. med. Ass. $172,443-448$ (1978).

23. O'ShEA, J. D., STUdDERT, M. J.: Growth of a autonomously replicating parvovirus (Feline Panleukopenia). Kinetics and morphogenesis. Arch. Virol. 57, 107-122 (1978).

24. Robinson, R. Q., Dowdik, W. R.: Influenza Viruses. In: Lensexwe, E. H., Schmid, N. J. (eds.), Diagnostic procedures for viral and rickettsial infections (fourth ed.), 414-433. New York: American Public Health Association Inc. 1969.

25. Stegt, G.: The Parvoviruses. (Virology Monographs 15), 109. Wien-New York: Springer 1976.

26. Simtн, K. O.: Identification of viruses by Flectron Microscopy. In: Busch, H. (ed.), Methods in Cancer Research, Vol. I, 545-572. New York: Academic Press 1967.

27. Trump, B. F., Smuckrar, E. A., Bendrot, E. P.: A method for staining epoxy sections for light microscopy. J. ultrastruct. Res. 5, 343-348 (1961).

28. Woode, G. N., BrIDGER, J. C.: Viral enteritis in Calves. Vet. Rec. 96, 85-88 (1975). Authors' address: Dr. G. Burtonsox, Laboratoire de Virologie, Clos Chapelle-auxChamps, 30.55, B-1200 Bruxelles, Belgium. 